\title{
Activation of anion redox in P3 structure cobalt-doped sodium manganese oxide via introduction of transition metal vacancies
}

Eun Jeong Kim, ${ }^{\S, \#, \Lambda}$ Kenza Mofredj, ${ }^{\S}$ David M. Pickup, ${ }^{\ddagger}$ Alan V. Chadwick, ${ }^{\ddagger}$ John T.S. Irvine, ${ }^{\S, \Lambda}$ A. Robert Armstrong*, $, \#, \Lambda$

${ }^{\S}$ School of Chemistry, University of St Andrews, St Andrews, Fife, KY16 9ST, United Kingdom

\# ALISTORE-ERI, 80039, Amiens Cedex, France

${ }^{\wedge}$ The Faraday Institution, Quad One, Harwell Science and Innovation Campus, Didcot, OX11 ORA, United Kingdom

${ }^{\text {F}}$ School of Physical Sciences, University of Kent, Canterbury, Kent CT2 7NH, United Kingdom Corresponding author

*E-mail: ara@st-andrews.ac.uk

\section{ABSTRACT}

Additional capacity delivered by oxygen redox activity may in principle represent a means of enhancing the electrochemical performance of layered sodium transition metal oxides. However, irreversible structural changes occurring during cycling typically cause significant capacity fade with limited reversibility of oxygen redox processes. Here, $\mathrm{P3}$-structure $\mathrm{Na}_{0.67} \mathrm{CO}_{0.2} \mathrm{Mn}_{0.8} \mathrm{O}_{2}$ was synthesised under two different reaction conditions. Both materials exhibit very stable cycling performance in the voltage range 1.8-3.8 $\mathrm{V}$ where the redox couples of transition metals entirely dominate the electrochemical reaction. For the compound prepared under more oxidising conditions, anion redox activity is triggered in the wider voltage window $1.8-4.4 \mathrm{~V}$ in a reversible manner with exceptionally small voltage hysteresis $(20 \mathrm{mV})$. The presence of vacancies in the transition metal layers is shown to 
play a critical role not only in generating unpaired $02 p$ states but also in stabilising the crystal structure in the high voltage region.

\section{KEYWORDS}

Sodium ion batteries, Layered oxides, Oxygen redox, Transition metal vacancies, P3 structure

\section{INTRODUCTION}

In order to meet ever-growing demand for energy storage systems, development of rechargeable batteries needs to consider not only their electrochemical performance but also sustainability and cost concerns. In this regard, sodium-ion batteries (SIBS) are a highly promising candidate to replace lithium-ion batteries (LIBs) in grid energy storage systems due to the high abundance of sodium.

Manganese-based sodium layered oxides, $\mathrm{Nax}_{\mathrm{yy}} \mathrm{Mn}_{1-\mathrm{y}} \mathrm{O}_{2}(0.4 \leq \mathrm{x} \leq 1.0,0.05 \leq \mathrm{y} \leq 0.5, \mathrm{M}=\mathrm{Li}, \mathrm{Mg}, \mathrm{Ti}$, $\mathrm{Fe}, \mathrm{Co}, \mathrm{Ni}, \mathrm{Zn}$ and mixture of elements) ${ }^{1,2}$ represent a major family of positive electrode materials for SIBs. They adopt one of the polymorphs O3, P3 and P2, depending on the type of coordination environment for $\mathrm{Na}^{+}$and the number of $\mathrm{MnO}_{2}$ slabs in the unit cell. ${ }^{3}$ The variety of structure type and composition is immense as a result of attempts to tune certain characteristics such as cyclability, rate capability, operating voltage and capacity. ${ }^{4,5}$ In general, substitution of spectator elements such as $\mathrm{Li}^{6}{ }^{6}$ $\mathrm{Mg}^{7,8}$ and $\mathrm{Zn}^{9}$ for $\mathrm{Mn}$ provides a rigid crystal structure during cycling, suppressing Jahn-Teller distortion at the expense of initial capacity. In order to increase initial capacity, the substitution of $\mathrm{Ni}$ for $\mathrm{Mn}$ has been explored through the $\mathrm{Ni}^{2+/ 4+}$ redox couple, however $\mathrm{Ni}$ substitution in $\mathrm{P} 2$-based materials gives rise to capacity fade because of the detrimental P2-O2 phase transformation occurring in the high voltage region ${ }^{10,11}$ and catalytical activity of $\mathrm{Ni}^{4+}$ which accelerates electrolyte decomposition. ${ }^{12}$ To alleviate the structural change, doping with $\mathrm{Li}^{13}$ and $\mathrm{Mg}^{14}$ has been adopted, increasing the amount of $\mathrm{Na}^{+}$left in the structure at the end of charge. In the case of Co as an electrochemically active dopant, its substitution for $\mathrm{Mn}$ in P2-type compounds improves cycle stability via diluting Jahn-Teller active $\mathrm{Mn}^{3+}$ by $\mathrm{Co}^{3+}$ and shows enhanced $\mathrm{Na}^{+}$kinetics. ${ }^{15,16}$ In the distorted P2-type compound, $\mathrm{P}^{\prime} 2$ 
$\mathrm{Na}_{2 / 3} \mathrm{Co}_{0.1} \mathrm{Mn}_{0.9} \mathrm{O}_{2}$, Co doping, while undesirable from a sustainability and cost perspective, also mitigates phase transition, resulting in enhanced cyclability. ${ }^{9}$

The nature of dopants in $\mathrm{Na} \times \mathrm{MyMn}_{1-\mathrm{y}} \mathrm{O}_{2}$ considerably influences oxygen redox, which represents an effective way to raise the energy density of positive electrode materials. For example, electrochemically inactive dopants such as $\mathrm{Li}^{17-19} \mathrm{Mg}^{20,21}$ and $\mathrm{Zn}^{22,23}$ produce non-bonding $\mathrm{O} 2 \mathrm{p}$ states at the top of valence band upon desodiation which participate in the charge compensation mechanism. The reversibility of oxygen redox varies as a function of the cationic ordering in transition metal layers, lattice $\mathrm{O}$ loss and migration of transition metals. In this regard, the presence of vacancies in the transition metal layers promotes reversible oxygen redox, maintaining crystal structure, suppressing voltage hysteresis and lifting working voltage. ${ }^{24-26}$ Among electrochemically active dopants, Ni can trigger oxygen redox through a reductive coupling mechanism and the creation of hybridisation between $\mathrm{Ni} 3 \mathrm{~d}$ and $\mathrm{O} 2 \mathrm{p}$ states in P3-type $\mathrm{Na}_{0.67} \mathrm{Ni}_{0.2} \mathrm{Mn}_{0.8} \mathrm{O}_{2 .}{ }^{27}$ Recently, P2-type $\mathrm{Na}_{0.6} \mathrm{Mg}_{0.2} \mathrm{CO}_{0.2} \mathrm{Mn}_{0.6} \mathrm{O}_{2}$ has been shown to exhibit reversible oxygen redox, even at high rate, driven by $\mathrm{Co}^{3+}$ with reduced bandgap energy and strong overlap between Co $3 \mathrm{~d}$ and $\mathrm{O} 2 \mathrm{p}$ states. ${ }^{28}$

Most of these studies have been carried out on $\mathrm{Na}_{x} \mathrm{MyMn}_{1-\mathrm{y}} \mathrm{O}_{2}$ phases adopting the $\mathrm{P} 2$ structure although the P3 structure is more environmentally friendly due to the lower sintering temperature compared to P2 equivalents. The difference in the oxygen stacking between P2 and P3 may lead to variation in electrochemical properties, in addition the introduction of vacancies in the transition metal layers for P3-type compounds may influence the oxygen redox activity. Thus, it is of interest to investigate the role of $\mathrm{Co}$ and vacancies in the transition metal layers for P3-type $\mathrm{Na}_{0.67} \mathrm{Co}_{0.2} \mathrm{Mn}_{0.8} \mathrm{O}_{2}$ as part of our ongoing studies of oxygen redox behaviour in P3-type $\mathrm{Na}_{x} \mathrm{MyMn}_{1-\mathrm{y}} \mathrm{O}_{2 .}{ }^{27}$

Here, we report on $\mathrm{P} 3$-type $\mathrm{Na}_{0.67} \mathrm{Co}_{0.2} \mathrm{Mn}_{0.8} \mathrm{O}_{2}$ prepared under two different synthetic conditions, varying sintering atmosphere and cooling rate in order to maximize the difference in the concentration of transition metal vacancies since simultaneous oxygen uptake under more oxidising conditions pushes the average $\mathrm{Mn}$ oxidation state towards $\mathrm{Mn}^{4+}$ and the charge compensation results in 
transition metal vacancies. ${ }^{29-34}$ The compound synthesised under oxygen with slow cooling and that prepared under air with quenching were thoroughly investigated providing complementary insight into electrochemical behaviour, electronic and crystal structure evolution. In the voltage range 1.8 - $3.8 \mathrm{~V}$, both compounds exhibit stable cycling performance, regardless of the presence of vacancies in the transition metal layers. The contrast in cyclability is significant in the voltage window 1.8 - 4.4 V where oxygen anions contribute to the charge compensation mechanism. Ex-situ Co and Mn XANES and PXRD measurements indicate that the vacancies solely found in the sample prepared under oxygen with slow cooling can trigger reversible oxygen redox with small polarisation and promote a robust crystal structure upon charge.

\section{MATERIAL AND METHODS}

A stoichiometric amount of sodium carbonate $\left(\mathrm{Na}_{2} \mathrm{CO}_{3}\right.$, Fisher Chemistry, $\left.\geq 99.5 \%\right)$ was dissolved in deionised water (solution A). A separate aqueous solution of cobalt (II) acetate tetrahydrate $\left(\mathrm{Co}\left(\mathrm{CH}_{3} \mathrm{CO}_{2}\right)_{2} \cdot 4 \mathrm{H}_{2} \mathrm{O}\right.$, Sigma-Aldrich, $\left.98+\%\right)$ and manganese (II) acetate tetrahydrate $\left(\mathrm{Mn}\left(\mathrm{CH}_{3} \mathrm{CO}_{2}\right)_{2} \cdot 4 \mathrm{H}_{2} \mathrm{O}\right.$, Sigma-Aldrich, $\left.99+\%\right)$ was prepared (solution B). The solution A was added dropwise to solution B under stirring then stirred for a further $10 \mathrm{~min}$. The water was removed using a rotary evaporator. The resulting solid was heated to $275^{\circ} \mathrm{C}$ for $12 \mathrm{~h}$ and cooled to $50^{\circ} \mathrm{C}$. The powder was then ground and heated to $625^{\circ} \mathrm{C}$ for $3 \mathrm{~h}$ under air and quenched; the obtained sample is denoted Air- $\mathrm{Na}_{0.67} \mathrm{Co}_{0.2} \mathrm{Mn}_{0.8} \mathrm{O}_{2}$. Alternatively, the decomposed powder was ground and heated to $625{ }^{\circ} \mathrm{C}$ for $3 \mathrm{~h}$ under oxygen then cooled to $50{ }^{\circ} \mathrm{C}$ to with a cooling rate of $5{ }^{\circ} \mathrm{C} \mathrm{min}-1$ to obtain Oxygen$\mathrm{Na}_{0.67} \mathrm{Co}_{0.2} \mathrm{Mn}_{0.8} \mathrm{O}_{2}$. The as-prepared materials were stored in an Ar-filled glovebox.

Powder X-ray diffraction (PXRD) patterns of the as-synthesised compounds were recorded on a PANalytical Empyrean diffractometer operating in transmission mode with Mo Ka radiation $(\lambda=$ $0.7107 \AA ̊$ A). Samples were contained in $0.7 \mathrm{~mm}$ glass capillaries. Structures were refined by the Rietveld method using Topas Academic v6. ${ }^{35}$ Scanning electron microscopy (SEM) images of the as-synthesised materials were recorded on a JEOL JSM-6700F. Co and Mn K-edge X-ray absorption near edge 
structure (XANES) measurements were performed at the beamline B18 at the Diamond Light source. ${ }^{36}$ The XANES spectra were collected in transmission mode and the intensities of both the incident and transmitted X-ray beams were measured using gas-filled ionization chambers. Reference spectra were collected for each measurement using Co and Mn metal foils which were placed in front of a third ionization chambers to allow the data to be corrected for any drift of the monochromator position and to permit accurate calibration of the energy scale. At least three scans were taken for each sample and the data were merged, calibrated, background subtracted and normalized using the program Athena. ${ }^{37}$

In order to evaluate the electrochemical performance of the materials, slurries were prepared using the active material (Air- $\mathrm{Na}_{0.67} \mathrm{Co}_{0.2} \mathrm{Mn}_{0.8} \mathrm{O}_{2}$ or Oxy-Na0.67 $\mathrm{Co}_{0.2} \mathrm{Mn}_{0.8} \mathrm{O}_{2}$ ), super $\mathrm{C} 65$ carbon and Solef 5130 binder (a modified polyvinylidene fluoride (PVDF)) in the mass ratio 75: 15: 10 in in n-methyl-2pyrrolidone, which was then cast on aluminium foil using a doctor blade. After drying, $13 \mathrm{~mm}$ diameter electrode discs were punched then dried at $80^{\circ} \mathrm{C}$ under vacuum for $12 \mathrm{~h}$. To prepare electrochemically cycled Air- $\mathrm{Na}_{0.67} \mathrm{Co}_{0.2} \mathrm{Mn}_{0.8} \mathrm{O}_{2}$ and $\mathrm{Oxy}-\mathrm{Na}_{0.67} \mathrm{Co}_{0.2} \mathrm{Mn}_{0.8} \mathrm{O}_{2}$ for ex-situ characterisation, working electrodes were constructed by mixing the active material (Air- $\mathrm{Na}_{0.67} \mathrm{Co}_{0.2} \mathrm{Mn}_{0.8} \mathrm{O}_{2}$ or Oxy$\left.\mathrm{Na}_{0.67} \mathrm{Co}_{0.2} \mathrm{Mn}_{0.8} \mathrm{O}_{2}\right)$, and super $\mathrm{C} 65$ carbon in the mass ratio $75: 25$. The mixture was dried at $110{ }^{\circ} \mathrm{C}$ under vacuum for $12 \mathrm{~h}$. The preparation of electrodes was carried out within $6 \mathrm{hrs}$ in ambient conditions. CR2325 coin cells were assembled in an Ar-filled glovebox and used for evaluation of electrochemical performance. The cells consisted of a disc electrode, sodium metal as a counter/reference electrode, a glass fibre separator (Whatman, GF/F) and the electrolyte $(1 \mathrm{M} \mathrm{NaClO} 4$ in propylene carbonate containing $3 \%$ fluoroethylene carbonate by weight). For all ex-situ measurements, Swagelok-type cells were assembled in an Ar-filled glovebox. The cells consisted of a desired amount of working electrode, consisted of $75 \mathrm{wt} \%$ active material and $25 \mathrm{wt} \%$ super $\mathrm{C} 65$ with no binder, sodium metal as a counter/reference electrode, glass fibre separators (Whatman, GF/F) and the electrolyte $(1 \mathrm{M} \mathrm{NaClO}$ in propylene carbonate containing $3 \%$ fluoroethylene carbonate by 
weight). Galvanostatic charge/discharge cycling and voltage scans (linear sweep voltammetry) were carried out at $30^{\circ} \mathrm{C}$ using a Maccor Series 4200 battery cycler.

For all ex-situ measurements, cycled cells were transferred to an Ar-filled glovebox before opening and the active material was extracted. The electrodes were rinsed carefully with dry dimethyl carbonate to remove residual electrolyte and then left under vacuum for $12 \mathrm{~h}$ to ensure all solvent had evaporated. XANES and PXRD measurements for cycled samples were carried out as described above.

\section{RESULTS AND DISCUSSION}

\subsection{Characterisation of as-synthesised materials}

Fitted PXRD patterns for both as-synthesised Air- $\mathrm{Na}_{0.67} \mathrm{Co}_{0.2} \mathrm{Mn}_{0.8} \mathrm{O}_{2}$ and $\mathrm{Oxy}-\mathrm{Na}_{0.67} \mathrm{Co}_{0.2} \mathrm{Mn}_{0.8} \mathrm{O}_{2}$ are shown in Figure 1a and b, respectively. The diffraction peaks for both compounds can be indexed on the basis of a simple P3 structural model (space group $R 3 m$ ), where Na ions occupy trigonal prismatic sites while Co and $\mathrm{Mn}$ are located in the octahedral sites in a trigonal unit cell with ABBCCA oxygen stacking. The Rietveld refinements of these two materials were carried out using a simple P3 structural model since a previous powder neutron diffraction study showed no in-plane ordering for a sample prepared under air and quenched. ${ }^{38}$ The results of the Rietveld refinement are presented in Table 1 and reveal a smaller unit cell parameter $a$ for $\mathrm{Oxy}-\mathrm{Na}_{0.67} \mathrm{Co}_{0.2} \mathrm{Mn}_{0.8} \mathrm{O}_{2}$ than that for Air$\mathrm{Na}_{0.67} \mathrm{CO}_{0.2} \mathrm{Mn}_{0.8} \mathrm{O}_{2}$, indicating a higher concentration of $\mathrm{Mn}^{4+}$ as a result of the more oxidising synthesis conditions using oxygen flow and slow cooling. ${ }^{7,}{ }^{34}$ In addition, a smaller unit cell parameter $c$ for Oxy$\mathrm{Na}_{0.67} \mathrm{Co}_{0.2} \mathrm{Mn}_{0.8} \mathrm{O}_{2}$ than that for Air- $\mathrm{Na}_{0.67} \mathrm{Co}_{0.2} \mathrm{Mn}_{0.8} \mathrm{O}_{2}$ is a good indicator of the formation of vacancies on the transition metal sites because the in-plane vacant sites bear a negative effective charge in the crystal structure. ${ }^{39}$ Such cell parameter changes may also result from variations in sodium content but, as shown below, the refined values in this case are essentially identical. The formation of vacancies in sodium manganese oxides under oxidising synthesis conditions has been known for many years. Examples include materials adopting the $\mathrm{P} 2$ structure and $\mathrm{Na}_{2} \mathrm{Mn}_{3} \mathrm{O}_{7} \cdot{ }^{24-26,29,31,40}$ Additionally, these 
conditions result in the formation of $6 \%$ vacancies in the transition metal layers as shown in the refined occupancies. The introduction of vacancies in the structural model resulted in an improved fit to the data ( $R_{w p}=3.31 \%$ vs $3.41 \%$ without vacancies) with more sensible refined occupancies relative to the starting composition. Henceforth the materials will be referred to by their refined compositions. The different synthetic conditions have a negligible influence on the morphology of the as-synthesised compounds which exhibit agglomerated primary particles of around $100 \mathrm{~nm}$ (Figure 1c-d).
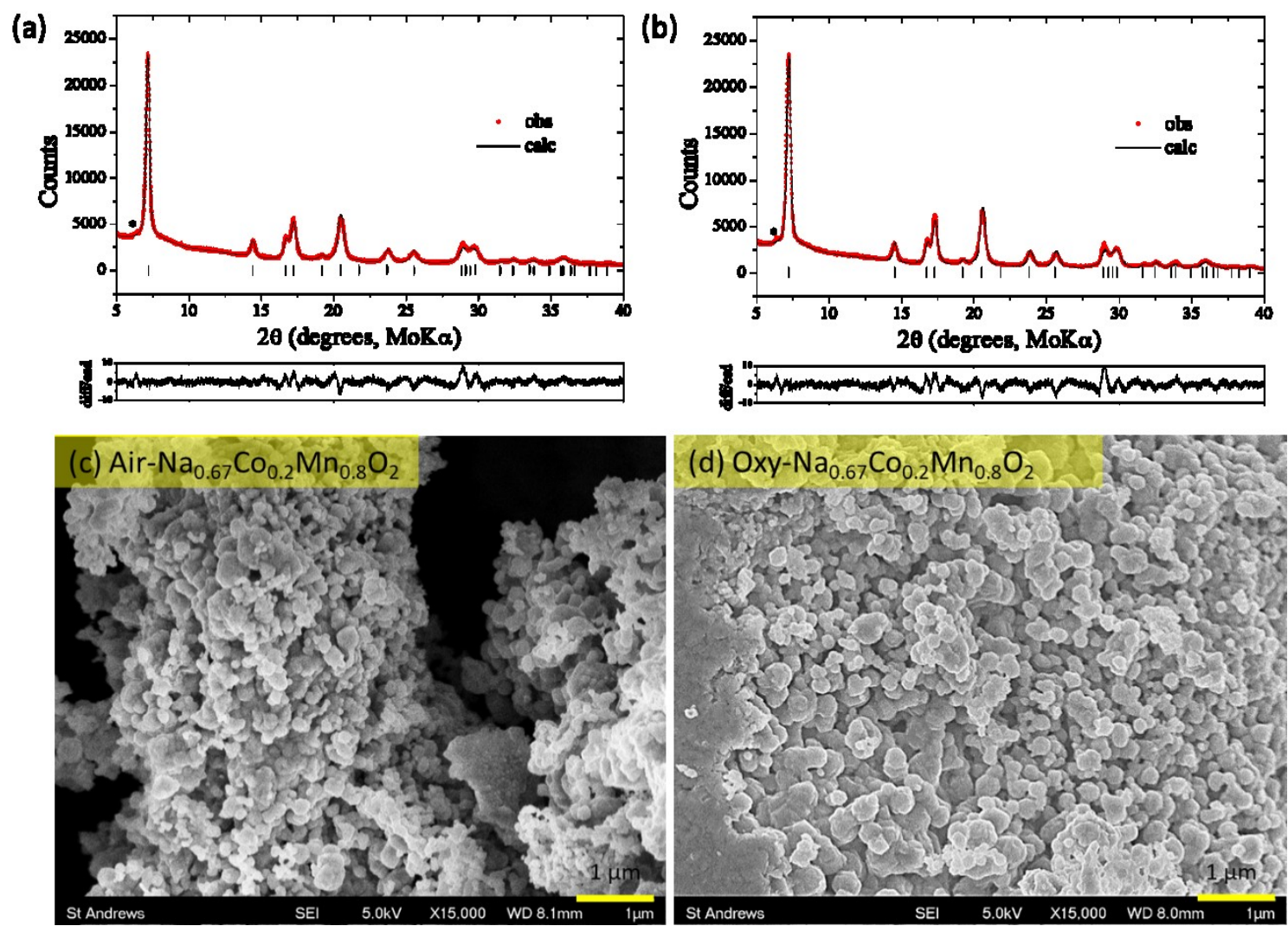

Figure 1. Profile fit for as-synthesised (a) Air- $\mathrm{Na}_{0.67} \mathrm{Co}_{0.2} \mathrm{Mnn}_{0.8} \mathrm{O}_{2}$ and (b) $\mathrm{Oxy}-\mathrm{Na}_{0.67} \mathrm{Co}_{0.2} \mathrm{Mn}_{0.8} \mathrm{O}_{2}$. Observed data points are shown in red, with fitted profile in black. Tick marks indicate allowed reflections for the P3 phase. The asterisk indicates the reflection from the capillary sample container. SEM images of as-synthesised (c) Air- $\mathrm{Na}_{0.67} \mathrm{Co}_{0.2} \mathrm{Mn}_{0.8} \mathrm{O}_{2}$ and (d) Oxy- $\mathrm{Na}_{0.67} \mathrm{Co}_{0.2} \mathrm{Mn}_{0.8} \mathrm{O}_{2}$. 
Table 1. Rietveld refinement results of (a) pristine Air- $\mathrm{Na}_{0.67} \mathrm{Co}_{0.2} \mathrm{Mn}_{0.8} \mathrm{O}_{2}$ and (b) pristine Oxy- $\mathrm{Na}_{0.67} \mathrm{Co}_{0.2} \mathrm{Mn}_{0.8} \mathrm{O}_{2}$.

\begin{tabular}{|c|c|c|c|c|c|c|}
\hline \multicolumn{7}{|c|}{ (a) Pristine Air- $\mathrm{Na}_{0.67} \mathrm{CO}_{0.2} \mathrm{Mn}_{0.8} \mathrm{O}_{2}$} \\
\hline \multicolumn{7}{|c|}{$R_{\text {exp }}=2.23 \%, R_{w p}=2.75 \%, 100 \%$ P3 } \\
\hline \multicolumn{7}{|c|}{ Lattice parameters P3 Space group $R 3 m a=b=2.8490(2) \AA, c=16.939(2) \AA$} \\
\hline atom & $\begin{array}{c}\text { Wyckoff } \\
\text { symbol }\end{array}$ & $\mathrm{x} / \mathrm{a}$ & $\mathrm{y} / \mathrm{b}$ & $\mathrm{z} / \mathrm{c}$ & Occupancy & Biso \\
\hline Co1/Mn1 & $3 a$ & 0 & 0 & 0 & $0.202(1) / 0.808(4)$ & 0.3 \\
\hline $\mathrm{Na} 1$ & $3 a$ & 0 & 0 & $0.1643(6)$ & $0.65(2)$ & $5.7(4)$ \\
\hline 01 & 3a & 0 & 0 & $0.3877(9)$ & 1 & 0.5 \\
\hline $\mathrm{O} 2$ & $3 a$ & 0 & 0 & $0.5997(7)$ & 1 & 0.5 \\
\hline
\end{tabular}

\begin{tabular}{|c|c|c|c|c|c|c|}
\hline \multicolumn{7}{|c|}{ (b) Pristine Oxy- $\mathrm{Na}_{0.67} \mathrm{Co}_{0.2} \mathrm{Mn}_{0.8} \mathrm{O}_{2}$} \\
\hline \multicolumn{7}{|c|}{$R_{\text {exp }}=2.34 \%, R_{w p}=3.31 \%, 100 \%$ P3 } \\
\hline \multicolumn{7}{|c|}{ Lattice parameters P3 Space group $R 3 m a=b=2.8418(2) \AA, c=16.856(2) \AA$} \\
\hline atom & $\begin{array}{l}\text { Wyckoff } \\
\text { symbol }\end{array}$ & $\mathrm{x} / \mathrm{a}$ & $y / b$ & $\mathrm{z} / \mathrm{c}$ & Occupancy & Biso \\
\hline Co1/Mn1 & $3 a$ & 0 & 0 & 0 & $0.189(1) / 0.756(4)$ & 0.3 \\
\hline $\mathrm{Na} 1$ & $3 a$ & 0 & 0 & $0.1626(4)$ & $0.64(1)$ & $4.3(2)$ \\
\hline 01 & $3 a$ & 0 & 0 & $0.3885(7)$ & 1 & 0.5 \\
\hline $\mathrm{O} 2$ & $3 a$ & 0 & 0 & $0.6018(6)$ & 1 & 0.5 \\
\hline
\end{tabular}

\subsection{Electrochemical properties}

Electrodes prepared with Air- $\mathrm{Na}_{0.65(2)} \mathrm{Co}_{0.202(1)} \mathrm{Mn}_{0.808(4)} \mathrm{O}_{2}$ and $\mathrm{Oxy}-\mathrm{Na}_{0.64(1)} \mathrm{Co}_{0.189(1)} \mathrm{Mn}_{0.756(4)} \mathrm{O}_{2}$ were cycled in two different voltage windows: $1.8-3.8 \mathrm{~V}$ and 1.8-4.4 V. Figure 2a shows the galvanostatic cycling performance of Air- $\mathrm{Na}_{0.65(2)} \mathrm{Co}_{0.202(1)} \mathrm{Mn}_{0.808(4)} \mathrm{O}_{2}$ and Oxy- $\mathrm{Na}_{0.64(1)} \mathrm{Co}_{0.189(1)} \mathrm{Mn}_{0.756(4)} \mathrm{O}_{2}$, cycled in the voltage window 1.8-3.8 V. In the narrower voltage window, both compounds exhibit stable cyclability with capacity retention of $94.4 \%$ and $100 \%$ over 20 cycles for Air- $\mathrm{Na}_{0.65(2)} \mathrm{Co}_{0.202(1)} \mathrm{Mn}_{0.808(4)} \mathrm{O}_{2}$ and Oxy- $\mathrm{Na}_{0.64(1)} \mathrm{Co}_{0.189(1)} \mathrm{Mn}_{0.756(4)} \mathrm{O}_{2}$, respectively. Coulombic efficiency of Oxy$\mathrm{Na}_{0.64(1)} \mathrm{Co}_{0.189(1)} \mathrm{Mn}_{0.756(4)} \mathrm{O}_{2}$ (around 99\%) is slightly higher than that of Air-Na0.65(2) $\mathrm{Co}_{0.202(1)} \mathrm{Mn}_{0.808(4)} \mathrm{O}_{2}$ (around 98\%) (Figure S1a). Oxy- $\mathrm{Na}_{0.64(1)} \mathrm{Co}_{0.189(1)} \mathrm{Mn}_{0.756(4)} \mathrm{O}_{2}$ delivers smaller first charge capacity of $27.3 \mathrm{mAh} \mathrm{g}^{-1}$, corresponding to the removal of $0.10 \mathrm{Na}^{+}$compared to that of Air$\mathrm{Na}_{0.65(2)} \mathrm{CO}_{0.202(1)} \mathrm{Mn}_{0.808(4)} \mathrm{O}_{2}$ (43.5 $\mathrm{mAh} \mathrm{g}^{-1}$, equivalent to deintercalation of $\left.0.16 \mathrm{Na}^{+}\right)$. As the 
electrochemical reaction is dominated by $\mathrm{Mn}$ redox in this voltage range, the smaller charge capacity is indicative of a lower content of $\mathrm{Mn}^{3+}$ in Oxy- $\mathrm{Na}_{0.64(1)} \mathrm{Co}_{0.189(1)} \mathrm{Mn}_{0.756(4)} \mathrm{O}_{2}$ and the difference in the deintercalated $\mathrm{Na}^{+}$agrees well with the concentration of transition metal vacancies. Typical charge/discharge profiles at cycle 2 for both compounds are shown in Figure $2 \mathrm{~b}$. The sample prepared under oxygen shows smaller cell polarisation with a smooth load curve and a steep slope followed by a distinctive plateau at around $2.1 \mathrm{~V}$. These characteristics of $\mathrm{Oxy}-\mathrm{Na}_{0.64(1)} \mathrm{Co}_{0.189(1)} \mathrm{Mn}_{0.756(4)} \mathrm{O}_{2}$ are reflected in the differential capacity versus voltage (dQ/dV) plots (Figure 2d) whilst Air$\mathrm{Na}_{0.65(2)} \mathrm{CO}_{0.202(1)} \mathrm{Mn}_{0.808(4)} \mathrm{O}_{2}$ exhibits several minor oxidation/reduction peaks above $2.6 \mathrm{~V}$ and broad redox peaks in the lower voltage region.

Given that the narrower voltage window provides stable cyclability, both compounds were cycled at higher rate $\left(100 \mathrm{~mA} \mathrm{~g}^{-1}\right)$ to investigate their rate capability. As shown in Figure 2e, Co substitution for Mn delivers $130 \mathrm{mAh} \mathrm{g}^{-1}$ and $140 \mathrm{mAh} \mathrm{g}^{-1}$ at the first cycle for Air- $-\mathrm{Na}_{0.65(2)} \mathrm{Co}_{0.202(1)} \mathrm{Mn}_{0.808(4)} \mathrm{O}_{2}$ and Oxy$\mathrm{Na}_{0.64(1)} \mathrm{CO}_{0.189(1)} \mathrm{Mn}_{0.756(4)} \mathrm{O}_{2}$, respectively, even at ten times faster rate. This faster rate can also mitigate the electrolyte decomposition, leading to enhanced capacity retention after 30 cycles $(99.2 \%$ and $100 \%$ for Air- $\mathrm{Na}_{0.65(2)} \mathrm{Co}_{0.202(1)} \mathrm{Mn}_{0.808(4)} \mathrm{O}_{2}$ and $\mathrm{Oxy}-\mathrm{Na}_{0.64(1)} \mathrm{Co}_{0.189(1)} \mathrm{Mn}_{0.756(4)} \mathrm{O}_{2}$, respectively) and better Coulombic efficiency than those at $10 \mathrm{~mA} \mathrm{~g}^{-1}$ (Figure S1b). The voltage profile curves at the faster rate at cycle 2 (Figure 2f) exhibit slightly increased cell polarisation that is more significant in the lower voltage region where the intercalation of additional $\mathrm{Na}^{+}$ions can induce the gliding of $\mathrm{Mn}(\mathrm{Co}) \mathrm{O}_{2}$ slabs, to form an $\mathrm{O}^{\prime} 3$ phase. It has been shown that the diffusion of $\mathrm{Na}^{+}$ions in prismatic sites (P-type structures) requires less activation energy than in octahedral sites (O-type structures) because $\mathrm{Na}^{+}$ions diffuse through shared faces between two neighbouring prismatic sites in the P-type structures whereas $\mathrm{Na}^{+}$ions pass via interstitial tetrahedral sites between two octahedral sites in the O-type structures. ${ }^{4,41}$ In line with previous studies, the enlarged polarisation in the lower voltage region is presumably a consequence of the slower $\mathrm{Na}^{+}$kinetics in the $\mathrm{O}^{\prime} 3$ structure. 

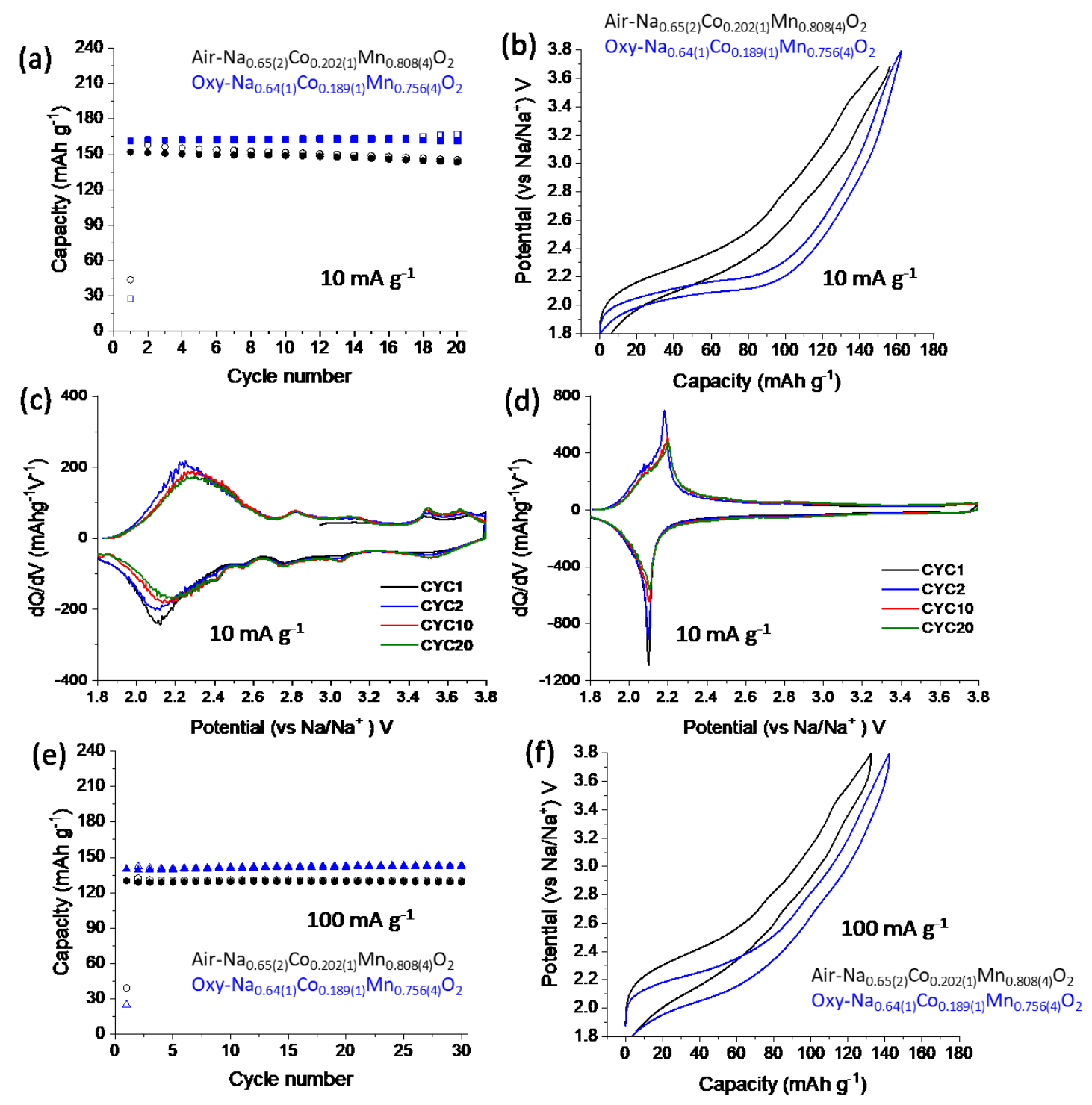

Figure 2. Galvanostatic cycling performance of Air- $\mathrm{Na}_{0.65(2)} \mathrm{Co}_{0.202(1)} \mathrm{Mn}_{0.808(4)} \mathrm{O}_{2}$ (black) and Oxy$\mathrm{Na}_{0.64(1)} \mathrm{Co}_{0.189(1)} \mathrm{Mn}_{0.756(4)} \mathrm{O}_{2}$ (blue) cycled at $30^{\circ} \mathrm{C}$ in the voltage range $1.8-3.8 \mathrm{~V}$ at a rate of (a) $10 \mathrm{~mA} \mathrm{~g}^{-1}$ and (e) $100 \mathrm{~mA} \mathrm{~g}^{-1}$. Empty and full symbols represent charge and discharge capacity, respectively. Charge/discharge curves of Air- $\mathrm{Na}_{0.65(2)} \mathrm{Co}_{0.202(1)} \mathrm{Mn}_{0.808(4)} \mathrm{O}_{2}$ (black) and Oxy-Na0.64(1) $\mathrm{Co}_{0.189(1)} \mathrm{Mn}_{0.756(4)} \mathrm{O}_{2}$ (blue) at cycle 2 cycled at $30{ }^{\circ} \mathrm{C}$ in the voltage range $1.8-3.8 \mathrm{~V}$ at a rate of (b) $10 \mathrm{~mA} \mathrm{~g}^{-1}$ and (f) $100 \mathrm{~mA} \mathrm{~g}^{-1}$. Differential capacity versus voltage plots corresponding to cycle 1 (black), cycle 2 (blue), cycle 10 (red) and cycle 20 (olive) for (c) Air- $\mathrm{Na}_{0.65(2)} \mathrm{Co}_{0.202(1)} \mathrm{Mn}_{0.808(4)} \mathrm{O}_{2}$ and (d) Oxy$\mathrm{Na}_{0.64(1)} \mathrm{CO}_{0.189(1)} \mathrm{Mn}_{0.756(4)} \mathrm{O}_{2}$ from (a). 
Increasing the upper cut-off voltage results in increased capacity fade for both compounds as shown in Figure 3a. The capacity fade is far more significant for Air- $\mathrm{Na}_{0.65(2)} \mathrm{Co}_{0.202(1)} \mathrm{Mn}_{0.808(4)} \mathrm{O}_{2}$, which maintains only $67.9 \%$ of its initial capacity whereas $\mathrm{Oxy}-\mathrm{Na}_{0.64(1)} \mathrm{Co}_{0.189(1)} \mathrm{Mn}_{0.756(4)} \mathrm{O}_{2}$ shows capacity retention of $89.1 \%$ after 20 cycles. A more intense irreversible oxidation peak at around $4.0 \mathrm{~V}$ in the $\mathrm{dQ} / \mathrm{dV}$ plots (Figure 3c) and lower Coulombic efficiency (Figure S1c) for Air- $\mathrm{Na}_{0.65(2)} \mathrm{Co}_{0.202(1)} \mathrm{Mn}_{0.808(4)} \mathrm{O}_{2}$ than Oxy- $\mathrm{Na}_{0.64(1)} \mathrm{Co}_{0.189(1)} \mathrm{Mn}_{0.756(4)} \mathrm{O}_{2}$ confirm lower capacity retention of the sample prepared under air with quenching. Interestingly, the sample synthesised under oxygen and slow cooling exhibits a reversible process (Figure $3 \mathrm{~b}$ ) with an oxidation peak at ca. $4.22 \mathrm{~V}$ and a coupled reduction peak at ca. 4.20 V on the first cycle, which persists over 10 cycles (Figure 3d). It is worth noting that this redox couple occurs with very small hysteresis (about $20 \mathrm{mV}$ ) and is exclusively observed in the presence of vacancies in the transition metal layers. The amount of $\mathrm{Na}^{+}$intercalated per formula unit associated with this redox couple is around 0.06, in good agreement with the vacancy content derived from the structure refinement (Table $1 b$ ). The sharp $d Q / d V$ peak at around $2.1 \mathrm{~V}$ for Oxy$\mathrm{Na}_{0.64(1)} \mathrm{CO}_{0.189(1)} \mathrm{Mn}_{0.756(4)} \mathrm{O}_{2}$ is indicative of a single redox process. ${ }^{42,43}$ In contrast, Air$\mathrm{Na}_{0.65(2)} \mathrm{Co}_{0.202(1)} \mathrm{Mn}_{0.808(4)} \mathrm{O}_{2}$ shows a broad dQ/dV peak with a smooth voltage profile in the low voltage region indicative of a range of redox processes. ${ }^{42,43}$ The presence of vacancies induces more covalent $\mathrm{Mn}(\mathrm{Co})-\mathrm{O}$ bond character that leads to the decrease of electrochemical potential. ${ }^{44}$ These features can be reconciled with the average working potentials of 2.56 and $2.69 \mathrm{~V}$ for Oxy$\mathrm{Na}_{0.64(1)} \mathrm{Co}_{0.189(1)} \mathrm{Mn}_{0.756(4)} \mathrm{O}_{2}$ and Air- $\mathrm{Na}_{0.65(2)} \mathrm{Co}_{0.202(1)} \mathrm{Mn}_{0.808(4)} \mathrm{O}_{2}$, respectively. In line with the widely reported behaviour of $\mathrm{Na}_{2} \mathrm{Mn}_{3} \mathrm{O}_{7}^{24-26}$ the reversible redox process in the high voltage region for Oxy$\mathrm{Na}_{0.64(1)} \mathrm{Co}_{0.189(1)} \mathrm{Mn}_{0.756(4)} \mathrm{O}_{2}$ is assumed to originate from oxygen redox associated with the vacancies in the transition metal layers.

Most of the oxygen redox processes activated by elemental substitutions in $\mathrm{Na}_{x} \mathrm{MyMn}_{1-\mathrm{y}} \mathrm{O}_{2}$ show significant hysteresis in their voltage profiles ${ }^{21,22}$ rendering the corresponding discharge process hard to distinguish in the galvanostatic cycling plots. In order to address this phenomenon, a series of cyclic voltammograms were collected by applying a progressively higher positive potential with a scan rate 
of $30 \mu \mathrm{V} \mathrm{s}{ }^{-1}$ from OCV to the upper cut-off voltage of $4.4 \mathrm{~V}$ with a voltage step of $0.3 \mathrm{~V}$, fixing the lower cut-off voltage at $1.8 \mathrm{~V}$ for each cycle. The voltammetric analysis for Air- $\mathrm{Na}_{0.65(2)} \mathrm{Co}_{0.202(1)} \mathrm{Mn}_{0.808(4)} \mathrm{O}_{2}$ is shown in Figure 3e. By gradually extending the upper cut-off voltage, a broad oxidation peak at $2.4 \mathrm{~V}$ and small oxidation peaks at $2.8 \mathrm{~V}, 3.1 \mathrm{~V}, 3.5 \mathrm{~V}$ and $3.7 \mathrm{~V}$ are compensated by corresponding reduction peaks in a reversible manner until the cut-off voltage of $3.8 \mathrm{~V}$. When the positive potential is extended to $4.1 \mathrm{~V}$, a new oxidation peak appears without any equivalent reduction peak on the following negative potential sweep. On the subsequent cycle, a small bump appears at the end of charge without any coupled reduction peak even at lower voltage, confirming the absence of high voltage redox activity. In the case of Oxy- $\mathrm{Na}_{0.64(1)} \mathrm{Co}_{0.189(1)} \mathrm{Mn}_{0.756(4)} \mathrm{O}_{2}$ (Figure 3f), a sharp redox couple is found at $2.1 \mathrm{~V}$ with only small redox peaks apparent in the middle voltage region. An irreversible oxidation peak appears at $4.0 \mathrm{~V}$ analogous to that observed in Air- $\mathrm{Na}_{0.65(2)} \mathrm{Co}_{0.202(1)} \mathrm{Mn}_{0.808(4)} \mathrm{O}_{2}$ but with much lower intensity. Extending the upper voltage limit to $4.4 \mathrm{~V}$ reveals a clear redox process with oxidation and reduction peaks at 4.22 and $4.21 \mathrm{~V}$, respectively. This redox couple is only observed in the material prepared under more oxidising synthetic conditions with oxygen flow and slow cooling. 
Air- $\mathrm{Na}_{0.65(2)} \mathrm{Co}_{0.202(1)} \mathrm{Mn}_{0.808(4)} \mathrm{O}_{2}$
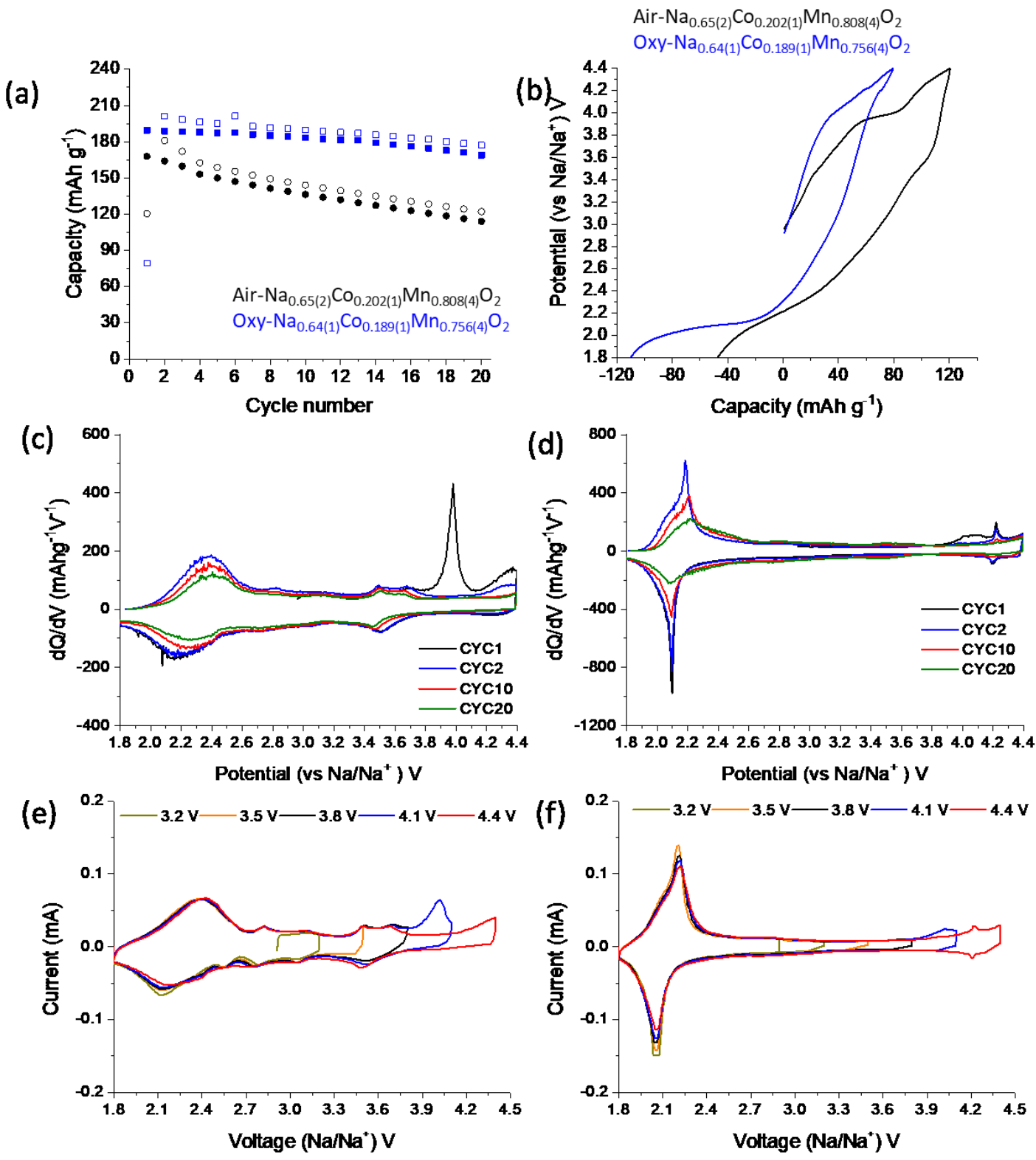

Figure 3. (a) Galvanostatic cycling performance of Air- $\mathrm{Na}_{0.65(2)} \mathrm{Co}_{0.202(1)} \mathrm{Mn}_{0.808(4)} \mathrm{O}_{2}$ (black) and Oxy$\mathrm{Na}_{0.64(1)} \mathrm{Co}_{0.189(1)} \mathrm{Mn}_{0.756(4)} \mathrm{O}_{2}$ (blue) cycled at $30{ }^{\circ} \mathrm{C}$ in the voltage range $1.8-4.4 \mathrm{~V}$ at a rate of $10 \mathrm{~mA} \mathrm{~g}^{-1}$. Empty and full symbols represent charge and discharge capacity, respectively. (b) Charge/discharge curves of Air- $\mathrm{Na}_{0.65(2)} \mathrm{Co}_{0.202(1)} \mathrm{Mn}_{0.808(4)} \mathrm{O}_{2}$ (black) and $\mathrm{Oxy}-\mathrm{Na}_{0.64(1)} \mathrm{Co}_{0.189(1)} \mathrm{Mn}_{0.756(4)} \mathrm{O}_{2}$ (blue) at cycle 1. Differential capacity versus voltage plots corresponding to cycle 1 (black), cycle 2 (blue), cycle 10 (red) and cycle 20 (olive) for (c) Air- $\mathrm{Na}_{0.65(2)} \mathrm{Co}_{0.202(1)} \mathrm{Mn}_{0.808(4)} \mathrm{O}_{2}$, (d) Oxy- $\mathrm{Na}_{0.64(1)} \mathrm{Co}_{0.189(1)} \mathrm{Mn}_{0.756(4)} \mathrm{O}_{2}$. Voltammetric analysis of (e) Air- $\mathrm{Na}_{0.65(2)} \mathrm{Co}_{0.202(1)} \mathrm{Mn}_{0.808(4)} \mathrm{O}_{2}$, (f) $\mathrm{Oxy}-\mathrm{Na}_{0.64(1)} \mathrm{Co}_{0.189(1)} \mathrm{Mn}_{0.756(4)} \mathrm{O}_{2}$ at a scan rate of $30 \mu \mathrm{V} \mathrm{s}$. 


\subsection{Charge compensation mechanism}

In order to study the changes in oxidation states of $\mathrm{Co}$ and $\mathrm{Mn}$ for both compounds during the first cycle, Co and Mn K-edge XANES spectra were collected at different states of charge (Figure 4a and 4b for Air- $\mathrm{Na}_{0.65(2)} \mathrm{Co}_{0.202(1)} \mathrm{Mn}_{0.808(4)} \mathrm{O}_{2}$ and Oxy- $\mathrm{Na}_{0.64(1)} \mathrm{Co}_{0.189(1)} \mathrm{Mn}_{0.756(4)} \mathrm{O}_{2}$, respectively) and their shoulder and main peak of the absorption edge, ascribed to the transition of $1 \mathrm{~s}$ to $4 \mathrm{p}$ states, were qualitatively compared with those of references. As shown in Figure 4c, pristine Air$\mathrm{Na}_{0.65(2)} \mathrm{CO}_{0.202(1)} \mathrm{Mn}_{0.808(4)} \mathrm{O}_{2}$ contains predominantly $\mathrm{Mn}^{4+}$ and its tetravalent state is largely unaffected upon charge to $4.4 \mathrm{~V}$ and subsequent discharge to $3.8 \mathrm{~V}$. In the pre-edge feature, corresponding to the transition from $1 \mathrm{~s}$ to $3 \mathrm{~d}$ states, the intensity increases continuously upon charge, indicating simultaneous distortion of the $\mathrm{Mn}(\mathrm{Co}) \mathrm{O}_{6}$ octahedron. ${ }^{45}$ Further discharge to $1.8 \mathrm{~V}$ exhibits a shift towards lower energy, corresponding to reduction of $\mathrm{Mn}^{4+}$ as more $\mathrm{Na}^{+}$ions are intercalated. For $\mathrm{Co}$ K-edge XANES spectra (Figure 4d), the position of the maximum of absorption for the pristine Air$\mathrm{Na}_{0.65(2)} \mathrm{Co}_{0.202(1)} \mathrm{Mn}_{0.808(4)} \mathrm{O}_{2}$ occurs at higher energy than $\mathrm{LiCoO}_{2}$ by $2.1 \mathrm{eV}$, corresponding to low-spin $\mathrm{Co}^{3+}$ as previous reported in $\mathrm{P} 2$-type $\mathrm{Na}_{2 / 3} \mathrm{CO}_{2 / 3} \mathrm{Mn}_{1 / 3} \mathrm{O}_{2} \cdot{ }^{46,47}$ It may be noted that the presence of $\mathrm{Co}^{4+}$ in the pristine sample is also feasible due to the deficiency of $\mathrm{Na}^{+}$ions. ${ }^{48}$ In addition, the spectral features of Co are sensitive to stacking sequence, requiring much attention to determine oxidation state with experimental fingerprints. ${ }^{49}$ Considering the difference of the oxygen stacking between O3type structure $\mathrm{LiCoO}_{2}\left(\mathrm{ABCABC} .\right.$. ) and P3-type Air-Na.65(2) $\mathrm{Co}_{0.202(1)} \mathrm{Mn}_{0.808(4)} \mathrm{O}_{2}$ (ABBCCA...), often accompanied by stacking faults associated with low temperature synthesis, it is likely that an admixture contribution of $\mathrm{Co}^{3+}$ and $\mathrm{Co}^{4+}$ is found in the pristine Air- $\mathrm{Na}_{0.65(2)} \mathrm{Co}_{0.202(1)} \mathrm{Mn}_{0.808(4)} \mathrm{O}_{2}$. The spectrum upon charge to $4.4 \mathrm{~V}$ and subsequent discharge to $3.8 \mathrm{~V}$ show little edge shift, implying that Co valence remains essentially same as the pristine material. At the end of discharge, the inflection point of the spectrum as well as of the half-height energy shift slightly towards lower energy, showing subtle reduction of Co cations. ${ }^{46}$ These results imply that a minority of $\mathrm{Mn}$ and Co participate in the charge compensation mechanism during desodiation before $3.8 \mathrm{~V}$ whilst the excess charge in the first cycle is attributable to electrolyte decomposition beyond 3.8 V. Irreversible oxygen activity such as 
lattice oxygen loss might also occur in Air- $\mathrm{Na}_{0.65(2)} \mathrm{Co}_{0.202(1)} \mathrm{Mn}_{0.808(4)} \mathrm{O}_{2}$, leading to the appearance of $\mathrm{O} 3$ phase at the end charge as confirmed by ex-situ PXRD. In the case of Oxy- $\mathrm{Na}_{0.64(1)} \mathrm{Co}_{0.189(1)} \mathrm{Mn}_{0.756(4)} \mathrm{O}_{2}$, the $\mathrm{Mn}$ oxidation state in the pristine sample is nearly $\mathrm{Mn}^{4+}$ and almost no shift is observed except for the sample at the end of discharge to $1.8 \mathrm{~V}$ (Figure 4e). The Co oxidation state of Oxy$\mathrm{Na}_{0.64(1)} \mathrm{CO}_{0.189(1)} \mathrm{Mn}_{0.756(4)} \mathrm{O}_{2}$ remains unchanged upon charge to $4.4 \mathrm{~V}$ and following discharge to $3.8 \mathrm{~V}$ (Figure 4f). More oxidising synthetic conditions promote a higher population of $\mathrm{Mn}^{4+}$ and $\mathrm{Co}^{4+}$ for the as-prepared sample (Figure S2), in good agreement with the reduced first charge capacity delivered in the narrow voltage window. The intensity of the pre-edge slightly increases when charged to $3.8 \mathrm{~V}$ but the intensity decreases upon further charge to $4.1 \mathrm{~V}$ and $4.4 \mathrm{~V}$. This implies electronic rearrangement takes place that permits stabilisation of $\mathrm{Mn}(\mathrm{Co}) \mathrm{O}_{6}$ possibly thanks to the vacancies. As a result of the electronic rearrangement in $3 d-4 p$ hybridisation, the intensity changes in the transition of $1 \mathrm{~s}$ to $4 \mathrm{p}$ states in Oxy- $\mathrm{Na}_{0.64(1)} \mathrm{Co}_{0.189(1)} \mathrm{Mn}_{0.756(4)} \mathrm{O}_{2}$. Electrolyte decomposition when charged to $4.4 \mathrm{~V}$ is also expected to occur in Oxy- $\mathrm{Na}_{0.64(1)} \mathrm{Co}_{0.189(1)} \mathrm{Mn}_{0.756(4)} \mathrm{O}_{2}$ since a major driving force of the decomposition is electrochemical instability of the electrolyte in the high voltage region. ${ }^{50}$ However, the near absence of shifts in $\mathrm{Mn}$ and Co XANES spectra in the voltage range 3.8-4.4 $\mathrm{V}$ for Oxy$\mathrm{Na}_{0.64(1)} \mathrm{Co}_{0.189(1)} \mathrm{Mn}_{0.756(4)} \mathrm{O}_{2}$ provides indirect evidence that the oxidation/reduction peaks at around 4.2 V originate from oxygen redox, which is solely found in Oxy- $\mathrm{Na}_{0.64(1)} \mathrm{Co}_{0.189(1)} \mathrm{Mn}_{0.756(4)} \mathrm{O}_{2}$, due to the presence of vacancies. Interestingly, the $\mathrm{Mn}$ and Co spectra of the end of discharge to $1.8 \mathrm{~V}$ shift towards even lower energy than those of Air- $\mathrm{Na}_{0.65(2)} \mathrm{Co}_{0.202(1)} \mathrm{Mn}_{0.808(4)} \mathrm{O}_{2}$, implying additional $\mathrm{Na}^{+}$ions are intercalated for Oxy- $\mathrm{Na}_{0.64(1)} \mathrm{Co}_{0.189(1)} \mathrm{Mn}_{0.756(4)} \mathrm{O}_{2}$, accompanying extra reduction of $\mathrm{Mn}$ and $\mathrm{Co}$. 
(a) $\mathrm{X}$ in Air- $\mathrm{Na}_{0.65(2)-\mathrm{x}} \mathrm{Co}_{0.202(1)} \mathrm{Mn}_{0.808(4)} \mathrm{O}_{2}$

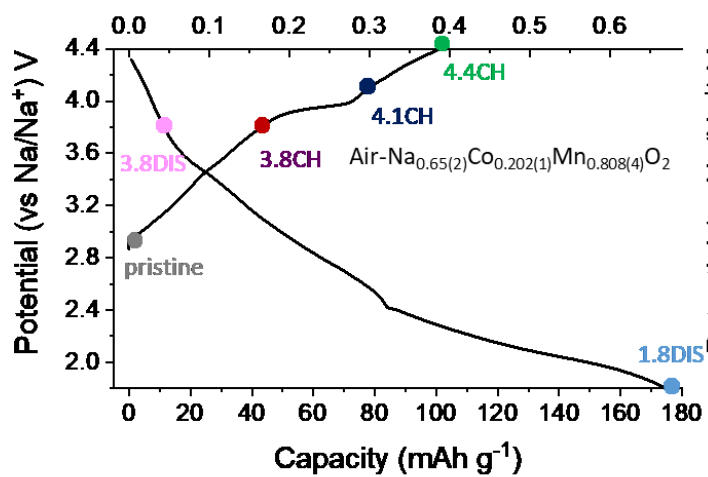

(c)

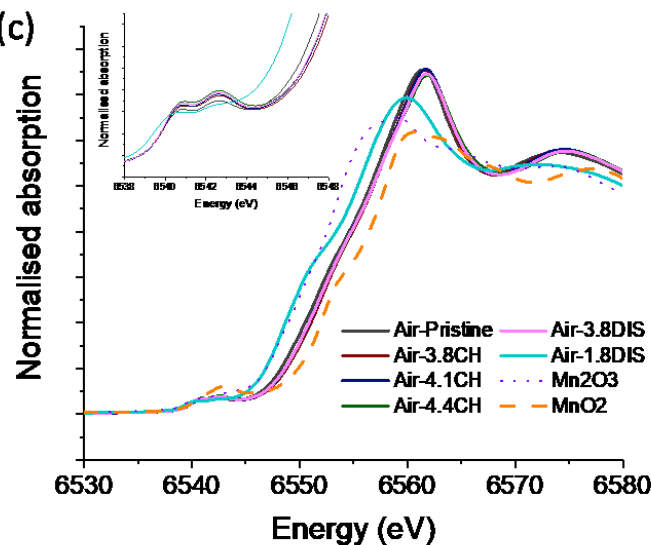

(e)

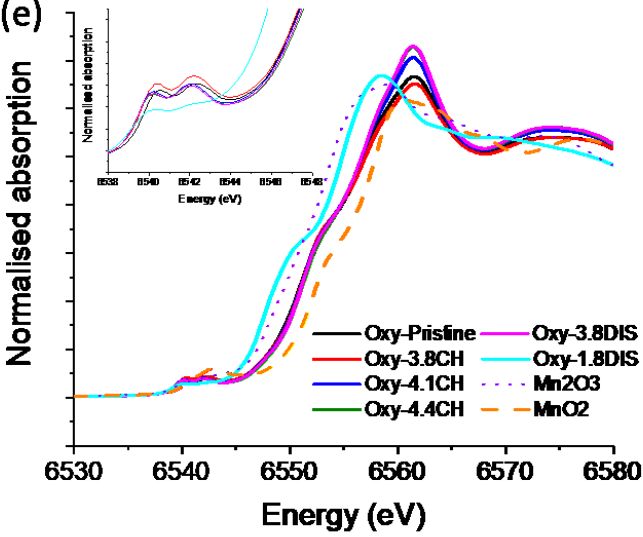

(b) $\mathrm{X}$ in Oxy- $\mathrm{Na}_{0.64(1)-\mathrm{x}} \mathrm{Co}_{0.189(1)} \mathrm{Mn}_{0.756(4)} \mathrm{O}_{2}$

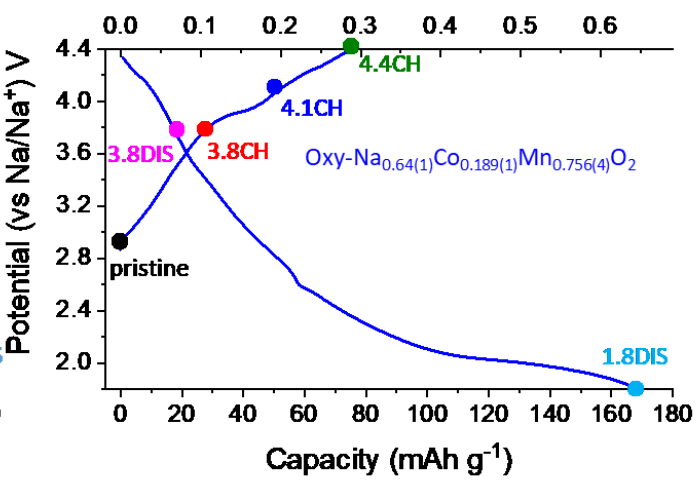

(d)

(f)
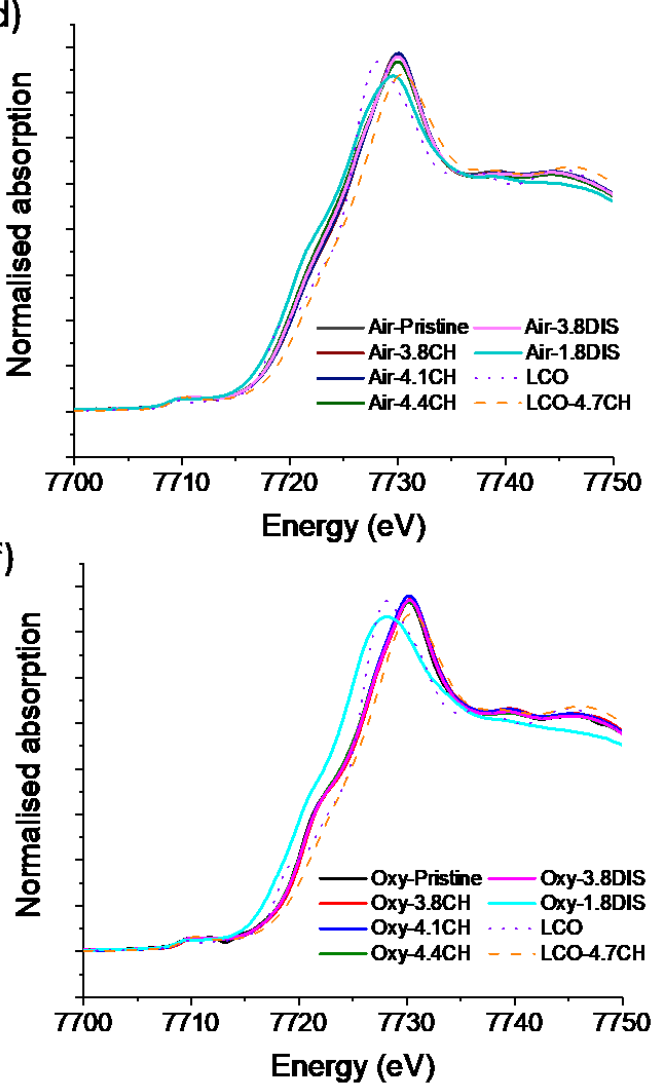

Figure 4. (a) Charge/discharge curves on the first cycle recorded at $10 \mathrm{~mA} \mathrm{~g}^{-1}$ for (a) Air$\mathrm{Na}_{0.65(2)} \mathrm{Co}_{0.202(1)} \mathrm{Mn}_{0.808(4)} \mathrm{O}_{2}$ and (b) Oxy- $\mathrm{Na}_{0.64(1)} \mathrm{Co}_{0.189(1)} \mathrm{Mn}_{0.756(4)} \mathrm{O}_{2}$ cycled between 1.8 $\mathrm{V}$ and $4.4 \mathrm{~V}$ with the points where XANES measurements were conducted. Mn K-edge XANES spectra of the ex-situ (c) Air- $\mathrm{Na}_{0.65(2)} \mathrm{Co}_{0.202(1)} \mathrm{Mn}_{0.808(4)} \mathrm{O}_{2}$, (e) Oxy-Na ${ }_{0.64(1)} \mathrm{Co}_{0.189(1)} \mathrm{Mn}_{0.756(4)} \mathrm{O}_{2}$ compared with reference of $\mathrm{Mn}^{3+}$ $\left(\mathrm{Mn}_{2} \mathrm{O}_{3}\right)$ and $\mathrm{Mn}^{4+}\left(\mathrm{MnO}_{2}\right)$ with an inset for the pre-edge and Co K-edge XANES spectra of the ex-situ (d) Air- $\mathrm{Na}_{0.65(2)} \mathrm{Co}_{0.202(1)} \mathrm{Mn}_{0.808(4)} \mathrm{O}_{2}$, (f) Oxy- $\mathrm{Na}_{0.64(1)} \mathrm{Co}_{0.189(1)} \mathrm{Mn}_{0.756(4)} \mathrm{O}_{2}$ compared with reference of $\mathrm{Co}^{3+}$ $\left(\mathrm{LiCoO}_{2}\right)$ and $\mathrm{Co}^{4+}\left(\mathrm{LiCoO}_{2}\right.$ charged to $\left.4.7 \mathrm{~V}\right)$. 


\subsection{Structural evolution}

Given that Air- $\mathrm{Na}_{0.65(2)} \mathrm{Co}_{0.202(1)} \mathrm{Mn}_{0.808(4)} \mathrm{O}_{2}$ shows an irreversible oxidation peak beyond $3.8 \mathrm{~V}$, delivering the excess charge capacity and the vacancies in Oxy- $\mathrm{Na}_{0.64(1)} \mathrm{Co}_{0.189(1)} \mathrm{Mn}_{0.756(4)} \mathrm{O}_{2}$ can stabilise $\mathrm{NaO}_{6}$ octahedra via the $\square-\mathrm{Na}^{+}-\square$ Coulombic attraction ( $\square$ : vacancies in the transition metal layers), ${ }^{51,52}$ ex-situ PXRD measurements were carried out at the end of charge and discharge on the first cycle in the voltage range 1.8-4.4 $\mathrm{V}$ to investigate the changes in the crystal structure.

Profile fits and refinement results are presented in Figure 5 and Table S1 for four ex-situ samples. Air$\mathrm{Na}_{0.65(2)} \mathrm{Co}_{0.202(1)} \mathrm{Mn}_{0.808(4)} \mathrm{O}_{2}$ at the end of charge exhibits $6(2) \%$ phase transformation from the $\mathrm{P} 3$ structure to an $\mathrm{O} 3$ structure, whereas $\mathrm{Oxy}-\mathrm{Na}_{0.64(1)} \mathrm{Co}_{0.189(1)} \mathrm{Mn}_{0.756(4)} \mathrm{O}_{2}$ maintains its $\mathrm{P} 3$ structure throughout the charging process. The unit cell parameter $a$ for the P3 phase decreases for both compounds as a result of the oxidation of $\mathrm{Mn}(\mathrm{Co})^{3+}$. The driving force for the $\mathrm{P} 3-\mathrm{O} 3$ transition is the minimisation of the Coulombic repulsion between adjacent $\mathrm{Mn}(\mathrm{Co}) \mathrm{O}_{2}$ slabs. As more sodium is removed, the screening between adjacent slabs in the P3 structure is reduced, thereby promoting the structural transition. ${ }^{29}$ The gliding of the transition metal oxygen slabs is poorly reversible, leading to large hysteresis in the charge/discharge profile for Air- $\mathrm{Na}_{0.65(2)} \mathrm{Co}_{0.202(1)} \mathrm{Mn}_{0.808(4)} \mathrm{O}_{2}$ (Figure 3b). ${ }^{21}$ In contrast, in-plane vacancies for Oxy- $\mathrm{Na}_{0.64(1)} \mathrm{Co}_{0.189(1)} \mathrm{Mn}_{0.756(4)} \mathrm{O}_{2}$ can minimise the P3-O3 transformation by maintaining a higher overall sodium content at the end of charge. In addition the structure may be pinned by the vacancies, via $\square-\mathrm{Na}^{+}-\square$ Coulombic attraction as well as $\mathrm{Na}^{+}-\mathrm{Mn}^{4+}$ Coulombic repulsion. ${ }^{51}$ The variation of the unit cell parameter $a$ between pristine and the charged samples is larger for Air- $\mathrm{Na}_{0.65(2)} \mathrm{Co}_{0.202(1)} \mathrm{Mn}_{0.808(4)} \mathrm{O}_{2}$, consistent with a higher $\mathrm{Mn}^{3+}$ population in the as-prepared state. The number of deintercalated $\mathrm{Na}$ ions is 0.24 and 0.22 per formula unit for Air$\mathrm{Na}_{0.65(2)} \mathrm{Co}_{0.202(1)} \mathrm{Mn}_{0.808(4)} \mathrm{O}_{2}$ and $\mathrm{Oxy}-\mathrm{Na}_{0.64(1)} \mathrm{Co}_{0.189(1)} \mathrm{Mn}_{0.756(4)} \mathrm{O}_{2}$, respectively based on the refinement results, which is smaller than those determined by the charge capacity (removal of 0.38 and $0.28 \mathrm{Na}^{+}$ for Air- $\mathrm{Na}_{0.65(2)} \mathrm{Co}_{0.202(1)} \mathrm{Mn}_{0.808(4)} \mathrm{O}_{2}$ and Oxy-Na0.64(1) $\mathrm{Co}_{0.189(1)} \mathrm{Mn}_{0.756(4)} \mathrm{O}_{2}$, respectively). This discrepancy is significantly larger for Air- $\mathrm{Na}_{0.65(2)} \mathrm{Co}_{0.202(1)} \mathrm{Mn}_{0.808(4)} \mathrm{O}_{2}$ consistent with the larger irreversible process 
above $4 \mathrm{~V}$ which may be attributable to the greater decomposition of the electrolyte as compared with Oxy- $\mathrm{Na}_{0.64(1)} \mathrm{Co}_{0.189(1)} \mathrm{Mn}_{0.756(4)} \mathrm{O}_{2}$. At the end of discharge, the major phase for both compounds is $\mathrm{O}^{\prime} 3$ with a minor amount of P3 phase $\left(19(2) \%\right.$ and $17(2) \%$ for Air- $\mathrm{Na}_{0.65(2)} \mathrm{Co}_{0.202(1)} \mathrm{Mn}_{0.808(4)} \mathrm{O}_{2}$ and Oxy$\mathrm{Na}_{0.64(1)} \mathrm{Co}_{0.189(1)} \mathrm{Mn}_{0.756(4)} \mathrm{O}_{2}$, respectively) because additional intercalation of $\mathrm{Na}^{+}$causes the formation of Jahn-Teller active $\mathrm{Mn}^{3+}$, confirmed by the XANES spectra. Although the degree of phase transformation to $\mathrm{O}^{\prime} 3$ is essentially equivalent, Oxy- $\mathrm{Na}_{0.64(1)} \mathrm{Co}_{0.189(1)} \mathrm{Mn}_{0.756(4)} \mathrm{O}_{2}$ exhibits significantly enhanced cyclability, presumably as a result of the changes occurring at the end of charge.

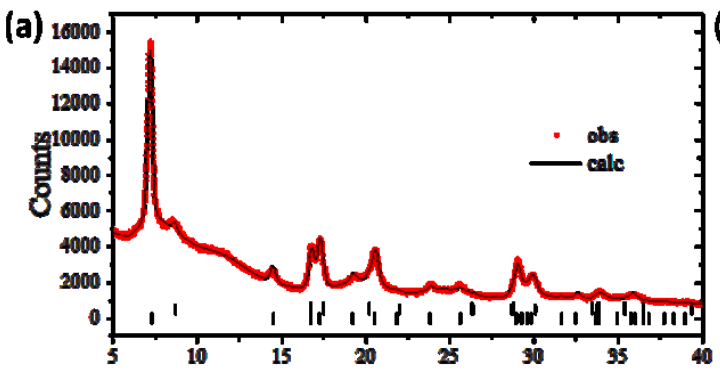

$2 \theta$ (degrees, MoKa)
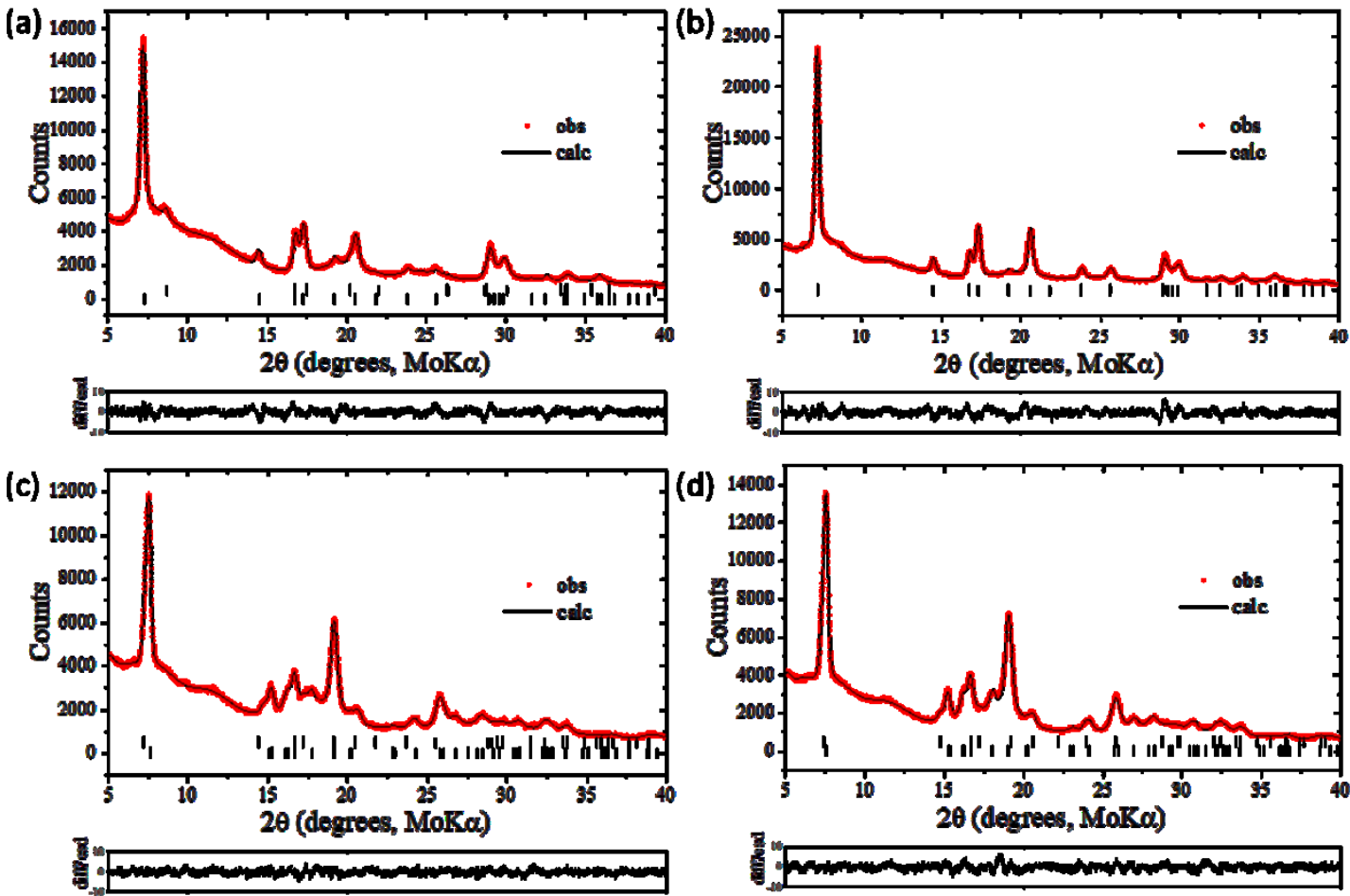

Figure 5. Profile fits for (a) Air- $\mathrm{Na}_{0.65(2)} \mathrm{Co}_{0.202(1)} \mathrm{Mn}_{0.808(4)} \mathrm{O}_{2}$ charged to $4.4 \mathrm{~V}$, (b) Oxy$\mathrm{Na}_{0.64(1)} \mathrm{Co}_{0.189(1)} \mathrm{Mn}_{0.756(4)} \mathrm{O}_{2}$ charged to $4.4 \mathrm{~V}$. (c) Air- $\mathrm{Na}_{0.65(2)} \mathrm{Co}_{0.202(1)} \mathrm{Mn}_{0.808(4)} \mathrm{O}_{2}$ charged to $4.4 \mathrm{~V}$ and discharged to $1.8 \mathrm{~V}$, (d) Oxy- $\mathrm{Na}_{0.64(1)} \mathrm{Co}_{0.189(1)} \mathrm{Mn}_{0.756(4)} \mathrm{O}_{2}$ charged to $4.4 \mathrm{~V}$ and discharged to $1.8 \mathrm{~V}$. Observed data points are shown in red, with fitted profile in black. Upper tick marks indicate allowed reflections for the $\mathrm{O} 3$ phase and lower tick marks for the P3 phase for (a). Upper tick marks indicate allowed reflections for the P3 phase and lower tick marks for the O'3 phase for (c) and (d). 


\section{CONCLUSIONS}

P3-type $\mathrm{Na}_{0.67} \mathrm{Co}_{0.2} \mathrm{Mn}_{0.8} \mathrm{O}_{2}$ prepared under two different synthetic conditions in order to vary the concentration of transition metal vacancies are shown to function as promising positive electrode materials with good cyclability in the voltage range $1.8-3.8 \mathrm{~V}$. The use of oxygen flow and slow cooling permit the creation of in-plane vacancies for P3-type $\mathrm{Na}_{0.67} \mathrm{Co}_{0.2} \mathrm{Mn}_{0.8} \mathrm{O}_{2}$. The presence of vacancies activates reversible oxygen redox beyond $3.8 \mathrm{~V}$ in the absence of the poorly reversible gliding of oxygen layers upon charge. This study paves a new route to realise oxygen redox in layered oxides without large voltage hysteresis that can deliver high energy density.

\section{ACKNOWLEDGEMENT}

EJK would like to thank the Alistore ERI for the award of a studentship. The authors are grateful for the provision of beam time and assistance from Dr. Nuria Tapia Ruíz and instrument scientists at beamline B18 at the Diamond Light Source as part of the Energy Materials Block Allocation Group SP14239. This work was supported by the Faraday Institution (grant number FIRG018) 


\section{REFERENCES}

(1) Ortiz-Vitoriano, N.; Drewett, N. E.; Gonzalo, E.; Rojo, T. High Performance Manganese-Based Layered Oxide Cathodes: Overcoming the Challenges of Sodium Ion Batteries. Energy Environ. Sci. 2017, 10, 1051-1074. https://doi.org/10.1039/c7ee00566k.

(2) Clément, R. J.; Bruce, P. G.; Grey, C. P. Review-Manganese-Based P2-Type Transition Metal Oxides as Sodium-Ion Battery Cathode Materials. J. Electrochem. Soc. 2015, 162, A2589A2604. https://doi.org/10.1149/2.0201514jes.

(3) Delmas, C.; Fouassier, C.; Hagenmuller, P. Structural Classicifation and Properties of the Layered Oxides. Phys. B 1980, 99, 81-85.

(4) Kubota, K.; Kumakura, S.; Yoda, Y.; Kuroki, K.; Komaba, S. Electrochemistry and Solid-State Chemistry of $\mathrm{NaMeO}_{2}$ (Me $=3 d$ Transition Metals). Adv. Energy Mater. 2018, 8, 17034151703455. https://doi.org/10.1002/aenm.201703415.

(5) You, Y.; Manthiram, A. Progress in High-Voltage Cathode Materials for Rechargeable SodiumIon Batteries. Adv. Energy Mater. 2018, 8, 1701785-1701796. https://doi.org/10.1002/aenm.201701785.

(6) De La Llave, E.; Talaie, E.; Levi, E.; Nayak, P. K.; Dixit, M.; Rao, P. T.; Hartmann, P.; Chesneau, F.; Major, D. T.; Greenstein, M.; Aurbach, D.; Nazar, L. F. Improving Energy Density and Structural Stability of Manganese Oxide Cathodes for Na-Ion Batteries by Structural Lithium Substitution. Chem. Mater. 2016, 28, 9064-9076. https://doi.org/10.1021/acs.chemmater.6b04078.

(7) Billaud, J.; Singh, G.; Armstrong, A. R.; Gonzalo, E.; Roddatis, V.; Armand, M.; Rojo, T.; Bruce, P. G. $\mathrm{Na}_{0.67} \mathrm{Mn}_{1-\mathrm{x}} \mathrm{Mg}_{\mathrm{x}} \mathrm{O}_{2}(0 \leq \mathrm{x} \leq 0.2)$ : A High Capacity Cathode for Sodium-Ion Batteries. Energy Environ. Sci. 2014, 7, 1387-1391. https://doi.org/10.1039/c4ee00465e.

(8) Clément, R. J.; Billaud, J.; Robert Armstrong, A.; Singh, G.; Rojo, T.; Bruce, P. G.; Grey, C. P. Structurally Stable Mg-Doped $\mathrm{P} 2-\mathrm{Na}_{2 / 3} \mathrm{Mn}_{1-y} \mathrm{Mg}_{y} \mathrm{O}_{2}$ Sodium-Ion Battery Cathodes with High 
Rate Performance: Insights from Electrochemical, NMR and Diffraction Studies. Energy Environ. Sci. 2016, 9, 3240-3251. https://doi.org/10.1039/c6ee01750a.

(9) Kumakura, S.; Tahara, Y.; Sato, S.; Kubota, K.; Komaba, S. $\mathrm{P}^{\prime} 2-\mathrm{Na}_{2 / 3} \mathrm{Mn}_{0.9} \mathrm{Me}_{0.1} \mathrm{O}_{2}(\mathrm{Me}=\mathrm{Mg}$, Ti, $\mathrm{Co}, \mathrm{Ni}, \mathrm{Cu}$, and $\mathrm{Zn}$ ): Correlation between Orthorhombic Distortion and Electrochemical $\begin{array}{llll}\text { Property. } & \text { Chem. }\end{array}$ https://doi.org/10.1021/acs.chemmater.7b02772.

(10) Lu, Z.; Dahn, J. R. In Situ X-Ray Diffraction Study of P2 $\mathrm{Na}_{2 / 3}\left[\mathrm{~N}_{\mathrm{i} / / 3} \mathrm{Mn}_{2 / 3}\right] \mathrm{O}_{2}$. J. Electrochem. Soc. 2001, 148, A1225-A1229.

(11) Lee, D. H.; Xu, J.; Meng, Y. S. An Advanced Cathode for Na-Ion Batteries with High Rate and Excellent Structural Stability. Phys. Chem. Chem. Phys. 2013, 15, 3304-3312. https://doi.org/10.1039/c2cp44467d.

(12) Hwang, J. Y.; S., Y. chong; Belharouak, I.; Sun, Y. K. A Comprehensive Study of the Role of Transition Metals in O3-Type Layered $\mathrm{Na}\left[\mathrm{Ni}_{x} \mathrm{Co}_{y} \mathrm{Mn}_{z}\right] \mathrm{O}_{2}(\mathrm{x}=1 / 3,0.5,0.6$, and 0.8) Cathodes for Sodium-Ion Batteries. J. Mater. Chem. A 2016, 4, 17952-17959. https://doi.org/10.1039/C6TA07392A.

(13) Xu, J.; Lee, D. H.; Clément, R. J.; Yu, X.; Leskes, M.; Pell, A. J.; Pintacuda, G.; Yang, X. Q.; Grey, C. P.; Meng, Y. S. Identifying the Critical Role of Li Substitution in P2-Nax $\left[\mathrm{Li}_{y} \mathrm{Ni}_{z} \mathrm{Mn}_{1-\mathrm{y}-\mathrm{z}}\right] \mathrm{O} 2(0<\mathrm{x}, \mathrm{y}$, $z<1)$ Intercalation Cathode Materials for High-Energy Na-Ion Batteries. Chem. Mater. 2014, 26, 1260-1269. https://doi.org/10.1021/cm403855t.

(14) Singh, G.; Tapia-Ruiz, N.; Lopez Del Amo, J. M.; Maitra, U.; Somerville, J. W.; Armstrong, A. R.; Martinez De llarduya, J.; Rojo, T.; Bruce, P. G. High Voltage Mg-Doped $\mathrm{Na}_{0.67} \mathrm{Ni}_{0.3-x} \mathrm{Mg}_{\mathrm{x}} \mathrm{Mn}_{0.7} \mathrm{O}_{2}$ $(x=0.05,0.1)$ Na-Ion Cathodes with Enhanced Stability and Rate Capability. Chem. Mater. 2016, 28, 5087-5094. https://doi.org/10.1021/acs.chemmater.6b01935.

(15) Konarov, A.; Kim, H. J.; Voronina, N.; Bakenov, Z.; Myung, S. T. P2- $\mathrm{Na}_{2 / 3} \mathrm{MnO}_{2}$ by Co 
Incorporation: As a Cathode Material of High Capacity and Long Cycle Life for Sodium-lon Batteries. ACS Appl. Mater. Interfaces 2019, 11, 28928-28933. https://doi.org/10.1021/acsami.9b09317.

(16) Bucher, N.; Hartung, S.; Franklin, J. B.; Wise, A. M.; Lim, L. Y.; Chen, H. Y.; Weker, J. N.; Toney, M. F.; Srinivasan, M. P2-Nax $\mathrm{Co}_{y} \mathrm{Mn}_{1-\mathrm{y}} \mathrm{O}_{2}(\mathrm{y}=0,0.1)$ as Cathode Materials in Sodium-Ion Batteries - Effects of Doping and Morphology to Enhance Cycling Stability. Chem. Mater. 2016, 28, 20412051. https://doi.org/10.1021/acs.chemmater.5b04557.

(17) Du, K.; Zhu, J.; Hu, G.; Gao, H.; Li, Y.; Goodenough, J. B. Exploring Reversible Oxidation of Oxygen in a Manganese Oxide. Energy Environ. Sci. 2016, 9, 2575-2577. https://doi.org/10.1039/c6ee01367h.

(18) Rong, X.; Liu, J.; Hu, E.; Liu, Y.; Wang, Y.; Wu, J.; Yu, X.; Page, K.; Hu, Y. S.; Yang, W.; Li, H.; Yang, X. Q.; Chen, L.; Huang, X. Structure-Induced Reversible Anionic Redox Activity in Na Layered Oxide Cathode. Joule 2018, 2, 125-140. https://doi.org/10.1016/j.joule.2017.10.008.

(19) House, R. A.; Maitra, U.; Pérez-Osorio, M. A.; Lozano, J. G.; Jin, L.; Somerville, J. W.; Duda, L. C.; Nag, A.; Walters, A.; Zhou, K.-J.; Roberts, M. R.; Bruce, P. G. Superstructure Control of FirstCycle Voltage Hysteresis in Oxygen-Redox Cathodes. Nature 2020, 577, 502-508. https://doi.org/10.1038/s41586-019-1854-3.

(20) Maitra, U.; House, R. A.; Somerville, J. W.; Tapia-Ruiz, N.; Lozano, J. G.; Guerrini, N.; Hao, R.; Luo, K.; Jin, L.; Pérez-Osorio, M. A.; Massel, F.; Pickup, D. M.; Ramos, S.; Lu, X.; McNally, D. E.; Chadwick, A. V.; Giustino, F.; Schmitt, T.; Duda, L. C.; Roberts, M. R.; Bruce, P. G. Oxygen Redox Chemistry without Excess Alkali-Metal lons in $\mathrm{Na}_{2 / 3}\left[\mathrm{Mg}_{0.28} \mathrm{Mn}_{0.72}\right] \mathrm{O}_{2}$. Nat. Chem. 2018, 10, 288295. https://doi.org/10.1038/nchem.2923.

(21) Song, B.; Hu, E.; Liu, J.; Zhang, Y.; Yang, X. Q.; Nanda, J.; Huq, A.; Page, K. A Novel P3-Type $\mathrm{Na}_{2 / 3} \mathrm{Mg}_{1 / 3} \mathrm{Mn}_{2 / 3} \mathrm{O}_{2}$ as High Capacity Sodium-Ion Cathode Using Reversible Oxygen Redox. J. 
Mater. Chem. A 2019, 7, 1491-1498. https://doi.org/10.1039/c8ta09422e.

(22) Bai, X.; Sathiya, M.; Mendoza-sánchez, B.; ladecola, A.; Vergnet, J.; Dedryvère, R.; Saubanère, M.; Abakumov, A. M.; Rozier, P.; Tarascon, J.; Gerhardt, I. C. Anionic Redox Activity in a Newly Zn-Doped Sodium Layered Oxide $\mathrm{P} 2-\mathrm{Na}_{2 / 3} \mathrm{Mn}_{1-\mathrm{y}} \mathrm{Zn}_{\mathrm{y}} \mathrm{O}_{2}(0<\mathrm{y}<0.23) .2018,2,1-13$. https://doi.org/10.1002/aenm.201802379.

(23) Konarov, A.; Jo, J. H.; Choi, J. U.; Bakenov, Z.; Yashiro, H.; Kim, J.; Myung, S. T. Exceptionally Highly Stable Cycling Performance and Facile Oxygen-Redox of Manganese-Based Cathode Materials for Rechargeable Sodium Batteries. Nano Energy 2019, 59, 197-206. https://doi.org/10.1016/j.nanoen.2019.02.042.

(24) Mortemard de Boisse, B.; Nishimura, S. ichi; Watanabe, E.; Lander, L.; Tsuchimoto, A.; Kikkawa, J.; Kobayashi, E.; Asakura, D.; Okubo, M.; Yamada, A. Highly Reversible Oxygen-Redox Chemistry at $4.1 \mathrm{~V}$ in Na4/7-x[ロ1/7Mn6/7]O2 ( $\square:$ Mn Vacancy). Adv. Energy Mater. 2018, 8, 1800409-1800416. https://doi.org/10.1002/aenm.201800409.

(25) Li, Y.; Wang, X.; Gao, Y.; Zhang, Q.; Tan, G.; Kong, Q.; Bak, S.; Lu, G.; Yang, X.-Q.; Gu, L.; Lu, J.; Amine, K.; Wang, Z.; Chen, L. Native Vacancy Enhanced Oxygen Redox Reversibility and Structural Robustness. Adv. Energy Mater. 2019, 9, 1803087-1803096. https://doi.org/10.1002/aenm.201803087.

(26) Song, B.; Tang, M.; Hu, E.; Borkiewicz, O. J.; Wiaderek, K. M.; Zhang, Y.; Phillip, N. D.; Liu, X.; Shadike, Z.; Li, C.; Song, L.; Hu, Y. Y.; Chi, M.; Veith, G. M.; Yang, X. Q.; Liu, J.; Nanda, J.; Page, K.; Huq, A. Understanding the Low-Voltage Hysteresis of Anionic Redox in $\mathrm{Na}_{2} \mathrm{Mn}_{3} \mathrm{O}_{7}$. Chem. Mater. 2019, 31, 3756-3765. https://doi.org/10.1021/acs.chemmater.9b00772.

(27) Kim, E. J.; Ma, L. A.; Duda, L. C.; Pickup, D. M.; Chadwick, A. V.; Younesi, R.; Irvine, J. T. S.; Armstrong, A. R. Oxygen Redox Activity through a Reductive Coupling Mechanism in the P3Type Nickel-Doped Sodium Manganese Oxide. ACS Appl. Energy Mater. 2020, 3, 184-191. 
https://doi.org/10.1021/acsaem.9b02171.

(28) Kim, H. J.; Konarov, A.; Jo, J. H.; Choi, J. U.; Ihm, K.; Lee, H. K.; Kim, J.; Myung, S. T. Controlled Oxygen Redox for Excellent Power Capability in Layered Sodium-Based Compounds. Adv. Energy Mater. 2019, 9, 1901181-1901190. https://doi.org/10.1002/aenm.201901181.

(29) Parant, J. P.; Olazcuaga, R.; Devalette, M.; Fouassier, C.; Hagenmuller, P. Sur Quelques Nouvelles Phases de Formule $\mathrm{Na}_{x} \mathrm{MnO}_{2}(\mathrm{x} \leq 1)$. J. Solid State Chem. 1971, 3, 1-11. https://doi.org/10.1016/0022-4596(71)90001-6.

(30) Fouassier, C.; Delmas, C.; Hagenmuller, P. Evolution Structurale et Proprietes Physiques Des Phases $\mathrm{AxMO}_{2}(\mathrm{~A}=\mathrm{Na}, \mathrm{K} ; \mathrm{M}=\mathrm{Cr}, \mathrm{Mn}, \mathrm{Co})(\mathrm{x} \leq 1)$. Mater. Res. Bull. 1975, 10, 443-449. https://doi.org/10.1016/0025-5408(75)90166-X.

(31) Stoyanova, R.; Carlier, D.; Sendova-Vassileva, M.; Yoncheva, M.; Zhecheva, E.; Nihtianova, D.; Delmas, C. Stabilization of Over-Stoichiometric $\mathrm{Mn} 4+$ in Layered $\mathrm{Na}_{2 / 3} \mathrm{MnO}_{2}$. J. Solid State Chem. 2010, 183, 1372-1379. https://doi.org/10.1016/j.jssc.2010.04.024.

(32) Armstrong, A. R.; Paterson, A. J.; Robertson, A. D.; Bruce, P. G. Nonstoichiometric Layered $\mathrm{Li}_{x} \mathrm{Mn}_{y} \mathrm{O}_{2}$ with a High Capacity for Lithium Intercalation/Deintercalation. Chem. Mater. 2002, 14, 710-719. https://doi.org/10.1021/cm010382n.

(33) Robertson, A. D.; Armstrong, A. R.; Bruce, P. G. Layered $\mathrm{Li}_{x} \mathrm{Mn}_{1-y} \mathrm{Co}_{y} \mathrm{O}_{2}$ Intercalation Electrodes - Influence of Ion Exchange on Capacity and Structure upon Cycling. Chem. Mater. 2001, 13, 2380-2386. https://doi.org/10.1021/cm000965h.

(34) Wang, X.; Tamaru, M.; Okubo, M.; Yamada, A. Electrode Properties of P2 $-\mathrm{Na}_{2 / 3} \mathrm{Mn}_{\mathrm{y}} \mathrm{Co}_{1-\mathrm{y}} \mathrm{O}_{2}$ as Cathode Materials for Sodium-Ion Batteries. J. Phys. Chem. C 2013, 117, 15545-15551. https://doi.org/10.1021/jp406433z.

(35) Coelho, A. A. Whole-Profile Structure Solution from Powder Diffraction Data Using Simulated Annealing. J. Appl. Crystallogr. 2000, 33, 899-908. 
https://doi.org/10.1107/\$002188980000248X.

(36) Dent, A. J.; Cibin, G.; Ramos, S.; Smith, A. D.; Scott, S. M.; Varandas, L.; Pearson, M. R.; Krumpa, N. A.; Jones, C. P.; Robbins, P. E. B18: A Core XAS Spectroscopy Beamline for Diamond. J. Phys. Conf. Ser. 2009, 190, 1-5. https://doi.org/10.1088/1742-6596/190/1/012039.

(37) Ravel, B.; Newville, M. ATHENA , ARTEMIS , HEPHAESTUS : Data Analysis for X-Ray Absorption Spectroscopy Using IFEFFIT. J. Synchrotron Radiat. 2005, 12, 537-541. https://doi.org/10.1107/S0909049505012719.

(38) Armstrong, A. R. Powder Neutron Diffraction Data. Unpuflished reesults.

(39) Tilley, R. J. D. Defect Crystal Chemistry and Its Applications. International Journal of High Technology Ceramics. Blackie: London 1988, https://doi.org/10.1016/0267-3762(88)90068-9.

(40) Zhao, C.; Wang, Q.; Lu, Y.; Jiang, L.; Liu, L.; Yu, X.; Chen, L.; Li, B.; Hu, Y. S. Decreasing Transition Metal Triggered Oxygen Redox Activity in Na-Deficient Oxides. Energy Storage Mater. 2019, 20, 395-400. https://doi.org/10.1016/j.ensm.2018.10.025.

(41) Yabuuchi, N.; Hara, R.; Kajiyama, M.; Kubota, K.; Ishigaki, T.; Hoshikawa, A.; Komaba, S. New O2/P2-Type Li-Excess Layered Manganese Oxides as Promising Multi-Functional Electrode Materials for Rechargeable Li/Na Batteries. Adv. Energy Mater. 2014, 4, 1301453-1301476. https://doi.org/10.1002/aenm.201301453.

(42) Bruce, P. G. Solid State Electrochemistry; Cambridge University Press, 2003.

(43) Liu, C.; Liu, C.; Neale, Z. G.; Cao, G.; Neale, Z. G.; Cao, G. Understanding Electrochemical Potentials of Cathode Materials in Rechargeable Batteries. Mater. Today 2016, 19, 109-123. https://doi.org/10.1016/j.mattod.2015.10.009.

(44) Melot, B. C.; Tarascon, J.-M. Design and Preparation of Materials for Advanced Electrochemical Storage. Acc. Chem. Res. 2012, 46, 1226-1238. https://doi.org/10.1021/ar300088q. 
(45) De Groot, F. M. F. X-Ray Absorption and Dichroism of Transition Metals and Their Compounds. J. Electron Spectros. Relat. Phenomena 1994, 67, 529-622. https://doi.org/10.1016/03682048(93)02041-J.

(46) Cheng, J.-H.; Pan, C.-J.; Lee, J. F.; Chen, J.-M.; Guignard, M.; Delmas, C.; Carlier, D.; Hwang, B. Simultaneous Reduction of $\mathrm{Co}^{3+}$ and $\mathrm{Mn}^{4+}$ in $\mathrm{P} 2-\mathrm{Na}_{2 / 3} \mathrm{CO}_{2 / 3} \mathrm{Mn}_{1 / 3} \mathrm{O}_{2}$ as Evidenced by X-Ray Absorption Spectroscopy during Electrochemical Sodium Intercalation. Chem. Mater. 2013, 26, 1219-1225. https://doi.org/10.1021/cm403597h.

(47) Hertz, J.; Huang, Q.; McQueen, T.; Klimczuk, T.; Bos, J.; Viciu, L.; Cava, R. Magnetism and Structure of $\mathrm{Li}_{x} \mathrm{CoO}_{2}$ and Comparison to $\mathrm{Na}_{x} \mathrm{CoO}_{2}$. Phys. Rev. B 2008, 77, 075119-175132.

(48) Berthelot, R.; Carlier, D.; Delmas, C. Electrochemical Investigation of the $\mathrm{P} 2-\mathrm{Na}_{x} \mathrm{CoO}_{2}$ Phase Diagram. Nat. Mater. 2011, 10, 74-80. https://doi.org/10.1038/nmat2920.

(49) Koyama, Y.; Arai, H.; Ogumi, Z.; Tanaka, I.; Uchimoto, Y. Co K-Edge XANES of $\mathrm{LiCoO}_{2}$ and $\mathrm{CoO}_{2}$ with a Variety of Structures by Supercell Density Functional Calculations with a Core Hole. Phys. Rev. B - Condens. Matter Mater. Phys. 2012, 85, 175129-175136. https://doi.org/10.1103/PhysRevB.85.075129.

(50) Eshetu, G. G.; Elia, G. A.; Armand, M.; Forsyth, M.; Komaba, S.; Rojo, T.; Passerini, S. Electrolytes and Interphases in Sodium-Based Rechargeable Batteries: Recent Advances and Perspectives. Adv. Energy Mater. 2020, 10, 2000093-2000134. https://doi.org/10.1002/aenm.202000093.

(51) Mortemard de Boisse, B.; Reynaud, M.; Ma, J.; Kikkawa, J.; Nishimura, S. ichi; Casas-Cabanas, M.; Delmas, C.; Okubo, M.; Yamada, A. Coulombic Self-Ordering upon Charging a LargeCapacity Layered Cathode Material for Rechargeable Batteries. Nat. Commun. 2019, 10 (1), 2185-2782. https://doi.org/10.1038/s41467-019-09409-1.

(52) Mortemard De Boisse, B.; Liu, G.; Ma, J.; Nishimura, S. I.; Chung, S. C.; Kiuchi, H.; Harada, Y.; Kikkawa, J.; Kobayashi, Y.; Okubo, M.; Yamada, A. Intermediate Honeycomb Ordering to Trigger 
Oxygen Redox Chemistry in Layered Battery Electrode. Nat. Commun. 2016, 7, 11397-11406. https://doi.org/10.1038/ncomms11397. 